\title{
Sensor less Speed Control of Three Phase Brush Less DC Motor Using Fuzzy Logic
}

\author{
Payal Athavale ${ }^{1}$, Gopal Chaudhari ${ }^{2}$, Ashish Zanjade ${ }^{3}$ \\ Electrical Department ${ }^{1,2,3}$, YTIET Mumbai University $^{1,2,3}$ \\ Email: athavale.payal@gmail.com ${ }^{1}$, gsc88@rediffmail.com², Zanjade_aa@rediffmail.com ${ }^{3}$
}

\begin{abstract}
In this paper, study of sensor less model for speed control of BLDC motor is illustrated. The use of BLDC motors has increased in different fields like robotics, automotive industry, wheel chairs etc. due to its low frictional losses and electrical characteristics. In this article it can be seen that there are many advantages of sensor less control over Hall sensor speed control. By replacing sensors by sensor less system we can achieve accurate detection of rotor position which in turn reduces maintenance cost and time of sensors. In this article implementation of Fuzzy Logic using Hardware model of BLDC motor is elaborated. This sensor less control method is preferable where access to motor is difficult as this system can be compiled in very small and compact units such as computer hard discs.
\end{abstract}

Keywords - BLDC Motor; Fuzzy Logic; Hall Sensors; Rotor Position; Sensor Less; Speed Control.

\section{INTRODUCTION}

In modern days new standards are deliberated by governments which increase the need of high performance parameters like efficiency and less electromagnetic interference. The advanced energy efficient drives use Permanent Magnet Brushless DC (BLDC) motors which have higher efficiency better power factor than cage motors. Use of BLDC motor for small horsepower application is increasing because of its high efficiency, silent operation, compact form, reliability, and low maintenance. However the complexity in control has become the limitation on use of BLDC motor. Due to the advancement in semiconductor devices, microprocessors, ICs Production of PMBLDC motors providing cost effective solution to adjustable speed applications.

Proposed system comprises of star connected 3 phase BLDC motor with intelligent electronic controller for power distribution. For proper commutation of current in respective stator winding, electronic controller requires accurate rotor position. Sensing of rotor position can be achieved by using Hall Sensors embedded in stator winding and thus windings are energised accordingly.

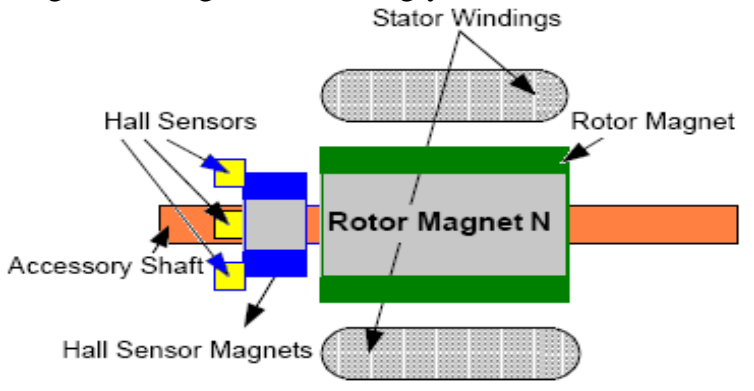

Fig. 1 Transverse section structure of a brushless dc motor
BLDC motor speed control can be done with sensor or by using sensor less system. Use of Hall sensors becomes more efficient being costlier than sensor less system as sensor less system gives low performance at transients and also gives low speed range with increase in complexity of control electronics. Embedded control of BLDC motors using PIC30f4013 generates a PWM signal that controls the inverter topology there by controlling the drive.

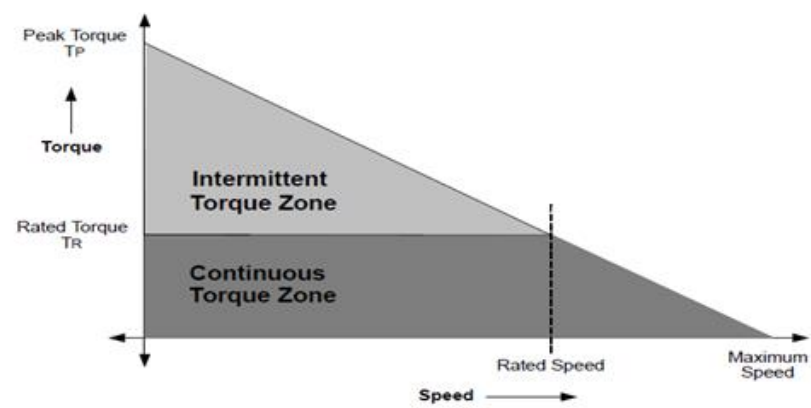

Fig. 2 Torque Speed Characteristic of BLDC motor

Table 1 Clockwise Hall Sensor Signals and Drive Signals

\begin{tabular}{|c|c|c|c|c|c|c|c|c|}
\hline$H a$ & $H b$ & $H c$ & $Q 1$ & $Q 2$ & $Q 3$ & $Q 4$ & $Q 5$ & $Q 6$ \\
\hline 0 & 0 & 0 & 0 & 0 & 0 & 0 & 0 & 0 \\
\hline 0 & 0 & 1 & 0 & 0 & 0 & 1 & 1 & 0 \\
\hline 0 & 1 & 0 & 0 & 1 & 1 & 0 & 0 & 0 \\
\hline 0 & 1 & 1 & 0 & 1 & 0 & 0 & 1 & 0 \\
\hline 1 & 0 & 0 & 1 & 0 & 0 & 0 & 0 & 1 \\
\hline 1 & 0 & 1 & 1 & 0 & 0 & 1 & 0 & 0 \\
\hline 1 & 1 & 0 & 0 & 0 & 1 & 0 & 0 & 1 \\
\hline
\end{tabular}




\section{Available online at www.ijrat.org}

\begin{tabular}{|l|l|l|l|l|l|l|l|l|}
\hline 1 & 1 & 1 & 0 & 0 & 0 & 0 & 0 & 0 \\
\hline
\end{tabular}

\section{MATHEMATICAL MODEL}

BLDC motor model is based on following assumptions

(1) All the stator phase windings have equal resistance per phase and constant self and mutual inductances.

(2) Power semiconductor devices are ideal.

(3) Iron losses are negligible and the motor is unsaturated.

Based on these assumptions the three phase input voltages can be expressed as:

$$
\begin{array}{ll}
\mathrm{v}_{\mathrm{a}}=\mathrm{Ri}_{\mathrm{a}}+\mathrm{L} \frac{\mathrm{di_{ \textrm {a } }}}{\mathrm{dt}}+\mathrm{e}_{\mathrm{a}} & \text { Eq. } 1 \\
v_{b}=R i_{b}+L \frac{d i_{b}}{d t}+e_{b} & \text { Eq. } 2 \\
\mathrm{v}_{\mathrm{c}}=\mathrm{Ri}_{\mathrm{c}}+\mathrm{L} \frac{\mathrm{di}_{\mathrm{c}}}{\mathrm{dt}}+\mathrm{e}_{\mathrm{c}} & \text { Eq. } 3
\end{array}
$$

The electromagnetic torque can be obtained by

$$
\mathrm{T}=\frac{1}{\omega}\left(e_{a} i_{a}+e_{b} i_{b}+e_{c} i_{c}\right) \quad \text { Eq. } 4
$$

Where

$\mathrm{R}$ : Stator resistance per phase, assumed to be equal for all phases

L: Stator inductance per phase, assumed to be equal for all phases.

ia, ib, ic: Stator current/phase.

$\mathrm{Va}, \mathrm{Vb}, \mathrm{Vc}$ : are the respective phase voltage of the winding

$\mathrm{e}_{\mathrm{a}} \mathrm{e}_{\mathrm{b}} \mathrm{e}_{\mathrm{c}}$ are back EMFs.

$\mathrm{R}$ : Stator resistance per phase, assumed to be equal for all phases

L: Stator inductance per phase, assumed to be equal for all phases.

ia, ib, ic: Stator current/phase.

$\mathrm{Va}, \mathrm{Vb}, \mathrm{Vc}$ : are the respective phase voltage of the winding

$\mathrm{e}_{\mathrm{a}} \mathrm{e}_{\mathrm{b}} \mathrm{e}_{\mathrm{c}}$ are back EMFs.

\section{PROPOSED MODEL}

In Figure 3, $\omega_{\text {ref. }}$ is the reference speed in $\mathrm{rad} / \mathrm{sec}, \omega_{\mathrm{a}}$ is the actual rotor speed in $\mathrm{rad} / \mathrm{sec}, \theta$ is the rotor position in degree, $\mathrm{u}$ is the control signal used to reference moment in $\mathrm{N}-\mathrm{m}, \mathrm{i}_{\mathrm{a}}, \mathrm{i}_{\mathrm{b}}, \mathrm{i}_{\mathrm{c}}$ are the actual phase currents in Ampere, $i_{a}$ ref, $i_{b}$ ref, $i_{c}$ ref are the reference phase currents in Ampere, $S 1$ - S6 are switches of the inverter and $\mathrm{V}_{\mathrm{dc}}$ is the supply voltage of the inverter in Volts.

As per the block diagram, the error signal is obtained by comparing reference speed and actual motor speed is employed in fuzzy controller along with reference current for control system. The current control loop consisting reference current generator, PWM current control unit and a three phase voltage source inverter (VSI) regulates the BLDC motor current to the reference current value generated by the speed controller. Rotor Position of the BLDC motor can be obtained by employing direct back EMF detection methods eliminating position sensor requirement.

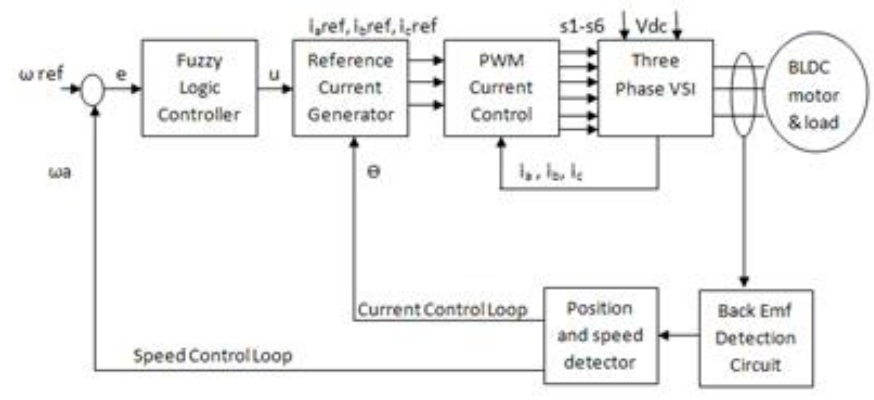

Fig. 3 Proposed Fuzzy logic for BLDC motor drive system.

\section{HARDWARE IMPLEMENTATION AND EXPERIMENTAL SETUP OF THE PROPOSED SYSTEM}

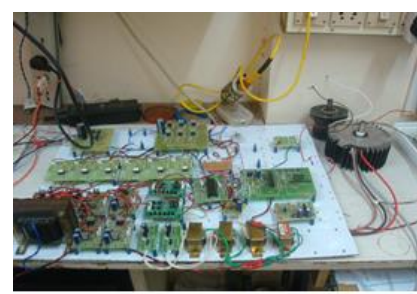

(a)

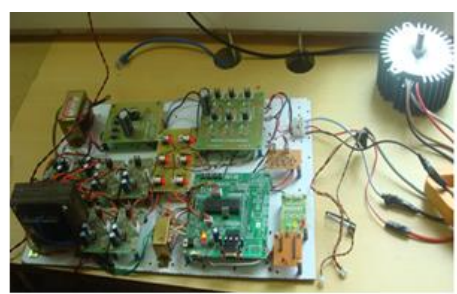

(b)
Fig. 4 Experimental Set-up of Project

Fig 4 shows the experimental set up of the project work. In fig (a) it can be seen the underdeveloped project and fig (b) shows the actual project which running successfully. This Experimental set up consists of a Brushless Dc motor, opto-coupler circuit, back EMF detector circuit, motor drive circuit, voltage regulator circuit, a voltage source and PIC30F4011 microcontroller board.

\section{RESULTS}

Implementation of sensor less BLDC is done successfully by using microcontroller PIC30F4011. Some key operating waveforms of sensor less BLDC motor are shown below: 


\section{Available online at www.ijrat.org}
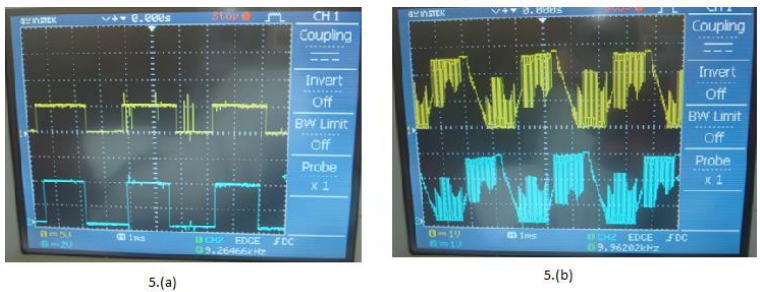

Fig. 5.(a) Output of One phase using Back Emf and HALL sensor ,Fig. 5.(b)Back Emf Waveform YN and $\mathrm{BN}$ phase through back Emf Detection Circuit
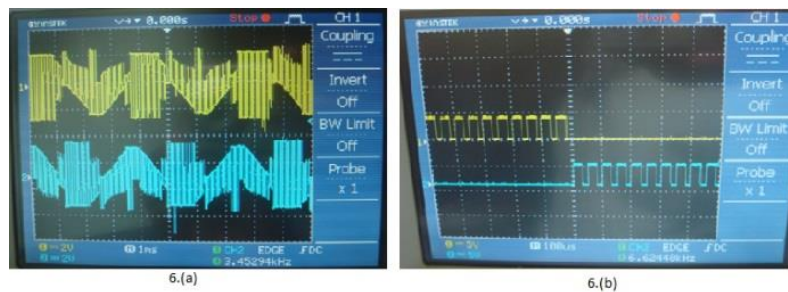

Fig. 6.(a) Back Emf Waveform RY and YB phase directly from Motor terminals,Fig. 6.(b) PWM pulse applied to MOSFETs of driver circuit
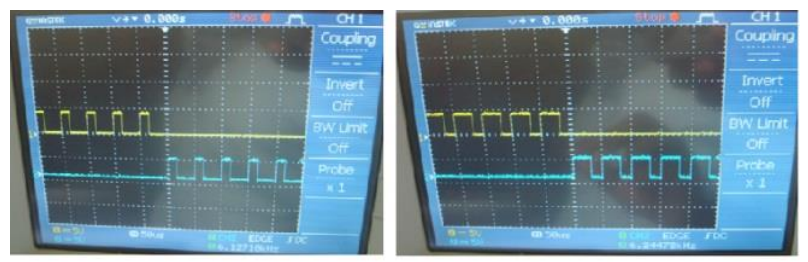

Fig. 7 Change in PWM duty cycle for speed Variations
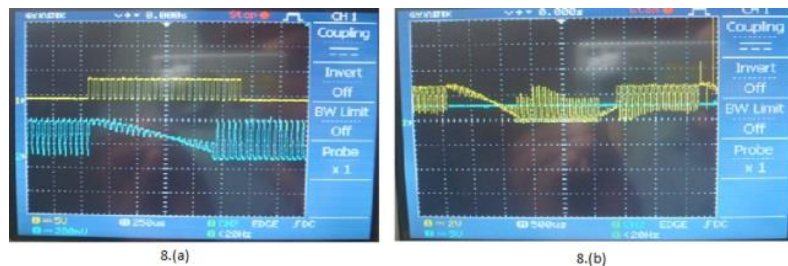

Fig. 8.(a) PWM pulse with the zero-crossing point, Fig. 8.(b) the zero-crossing point and DC bus

Figure 5.(a) shows the output monitored at one phase of the motor through microcontroller circuit and another signal is taken from the output of the hall sensor. Figure shows the relationship between the hall sensor signals and the back Emf signals. Figure 5.(b) shows Back Emf Waveform of $\mathrm{R}$ phase with respect to neutral point $\mathrm{N}$ and $\mathrm{Y}$ phase with respect to neutral point $\mathrm{N}$ through back Emf Detection Circuit. The motor windings produce trapezoidal back Emf. The back Emf generated in the windings are at 120 degrees out of phase to each other. Figure 6.(a) shows Back
Emf Waveform RY and YB phase directly from Motor terminals i.e without using back Emf detection circuit and it is clear that it is difficult to identify the zero crossing at these terminals. PWM pulse applied to MOSFETs of driver circuit. Which provide the control action for turning on and off of electronic switches for proper commutation of motor. Change in PWM duty cycle for different speed variations. Motor speed is directly proportional to applied voltage, so varying the PWM duty cycle linearly from $0 \%$ to $100 \%$ will result in a linear speed control from $0 \%$ to $100 \%$ of maximum RPM. Figure 5.b shows PWM pulse and the zero-crossing point of back Emf waveform and the zero-crossing point and DC bus.

\section{CONCLUSION}

The proposed compact, cost effective, robust sensor less speed control system for BLDC motor using PIC30F4011 microcontroller is designed, implemented and tested successfully. It is tested by varying set speed and motor speed. The results obtained are satisfactory. It is observed that this system is less affected by electromagnetic interference and noise signals. This system can be used in variable speed applications like Electrical Vehicles, Robotics etc. along with it this speed control method provides accurate results as compared to sensor speed control.

\section{REFERENCES}

[1] T.J.E. Miller, „'Brushless Permanent Magnet \& Reluctance Motor Drives Clarendon Press, Oxford, Vol.2, pp: 192-199, 1989.

[2] J.A. Oyedepo and A. Folaponmile "Implementation of a Fuzzy Logic Speed Controller for a Permanent Magnet Brushless DC Motor drive system”. JORIND December, 11.

[3] Mr.R.Vijayarajeswaran, "TMS320F2812 Based Implementation of sensorless Control for BLDC Motor" (IJEST) Vol. 3 No. 10 October 2011.

[4] A. A. Hassan, and M. Azzam "Robust control of a Speed Sensorless Permanent Magnet Synchronous Motor Drive".

[5] N.Senthil Kumar "Design and Implementation of Adaptive Fuzzy Controller for Speed Control of Brushless DC Motors" (IJCA) Vol.1 2010.

[6] R.Shanmugasundram , K.Muhammed Zakariah, and N.Yadaiah "Digital Implementation of Fuzzy Logic Controller for Wide Range Speed Control of Brushless DC Motor" (ICVES) 2009.

[7] Narmadha T.V. and Thyagarajan T.” Fuzzy Logic Based Position-Sensorless Speed Control of Multi Level Inverter Fed PMBLDC Drive" (JOAIT) Vol 1 Feb 2010.

[8] Tan Chee Siong, Baharuddin Ismail, Siti Fatimah Siraj, Mohd Fayzul Mohammed "Fuzzy Logic 
International Journal of Research in Advent Technology, Vol.7, No.5, May 2019

E-ISSN: 2321-9637

Available online at www.ijrat.org

Controller for BLDC Permanent Magnet Motor Drives "IJECS-IJENS Vol: 11 No: 02.

[9] C. Subba Rami Reddy And M. Surya Kalavathi "Performance Evaluation Of Hybrid Fuzzy Logic Controller For Brushless Dc Motor Drive" (Ijest) Vol 3 June 2011.

[10] A. Tashakori, Member IAENG, M. Ektesabi, Member IAENG and N. Hosseinzadeh "Modeling of BLDC Motor with Ideal BackEMF for Automotive Applications" WCE 2011, July 6 - 8, 2011, London, U.K..

[11]R. Saxena, Y. Pahariya, A. Tiwary, "Modeling and simulation of BLDC motor using soft computing techniques", Second International Conference on Communication Software and Networks, 2010, ICCSN '10, 26- 28 Feb, Singapore. 